\title{
PENGARUH PEMBERIAN UBI JALAR UNGU (Ipomoea batatas L. Poir) TERHADAP KADAR LEUKOSIT TOTAL TIKUS WISTAR JANTAN (Rattus norvegicus) YANG DIPAPAR ASAP ROKOK
}

\author{
Fadilla Rahma, Martha Ardiaria, Binar Panunggal* \\ Departemen Ilmu Gizi, Fakultas Kedokteran, Universitas Diponegoro \\ Jln. Prof. H. Soedarto, SH., Semarang, Telp (024) 76402881, Email : dept-gizi@fk.undip.ac.id
}

\begin{abstract}
Background : Cigarette smoke is exogenous sources of free radicals that can stimulate the inflammation mediators secretion resulting an inflammation response on the body. Leukocyte levels can be used as measurement method of inflammatory marker. Purple sweet potato is known for its antioxidant content which potentially decrease negative effect of free radicals.

Objective : To analyze the effect of purple sweet potato on total leukocyte levels in rats which exposed to cigarette smoke. Method: This study was post test only control group design. It was using 24 male wistar rats which divided into 4 groups: the $K(-)$ group, $K(+)$ group that rats exposed with cigarette smoke, P1 group that rats given purple sweet potato 8 g/200 $\mathrm{g} B W$, and $P 2$ group that rats exposed with cigarette smoke and given purple sweet potato $8 \mathrm{~g} / 200 \mathrm{~g} B W$. The intervention was given for 30 days. Statistical analysis was using One-way ANOVA.

Results : There were no significant differences in total leukocyte levels among treatment groups $(p=0,579)$. The highest total leukocyte level was in $\mathrm{K}(+)$ group $23.56 \pm 3.10 \times 10^{3} / \mathrm{mm}^{3}$. P2 group had total leukocyte level $21.36 \pm 3.52 \times 10^{3} / \mathrm{mm}^{3}$. Conclusion: There are no significant differences in total leukocyte levels rats which exposed to cigarette smoke and given purple sweet potato with other treatment groups.
\end{abstract}

Keywords : Purple sweet potato, cigarette smoke, total leukocyte.

\section{ABSTRAK}

Latar belakang: Asap rokok merupakan salah satu sumber radikal bebas eksogen yang dapat menstimulasi sekresi mediator inflamasi sehingga tubuh memberikan respon inflamasi. Kadar leukosit dapat digunakan sebagai indikator untuk melihat adanya inflamasi dalam tubuh. Ubi jalar ungu diketahui mengandung antioksidan yang berpotensi mengurangi efek negatif dari radikal bebas.

Tujuan: Menganalisis pengaruh pemberian ubi jalar ungu terhadap kadar leukosit total tikus yang dipapar asap rokok. Metode: Jenis penelitian ini adalah post-test only control group design. Besar sampel penelitian berjumlah 24 ekor tikus wistar jantan yang dibagi ke dalam 4 kelompok, yaitu kelompok $K(-)$, kelompok $K(+)$ yang diberi paparan asap rokok, kelompok P1 yang diberi ubi jalar ungu $8 \mathrm{~g} / 200 \mathrm{~g}$ BB, dan kelompok P2 yang diberi paparan asap rokok serta ubi jalar ungu 8 g/200 g BB. Perlakuan dilakukan selama 30 hari. Analisis statistik menggunakan uji One-way ANOVA.

Hasil: Tidak terdapat perbedaan kadar leukosit total yang signifikan antar kelompok perlakuan (p=0,579). Kadar leukosit total tertinggi berada pada kelompok $\mathrm{K}(+)$ dengan nilai $23.56 \pm 3.10 \times 10^{3} / \mathrm{mm}^{3}$. Kelompok P2 memiliki kadar leukosit total sebesar $21.36 \pm 3.52 \times 10^{3} / \mathrm{mm}^{3}$.

Simpulan: Pemberian ubi jalar ungu tidak menunjukkan adanya perbedaan yang signifikan terhadap kadar leukosit total tikus yang dipapar asap rokok.

Kata kunci: Ubi jalar ungu, asap rokok, leukosit total

\section{PENDAHULUAN}

Merokok merupakan salah satu faktor yang dapat mengganggu kesehatan tubuh. Merokok diketahui sebagai faktor risiko dari perkembangan penyakit kardiovaskular, penurunan masa otot terkait usia, penyakit paru-paru kronik, stroke, penyakit Alzheimer, penyakit Parkinson, dan kematian dini. ${ }^{1,2,3}$ Menurut hasil penelitian diketahui risiko penyakit jantung koroner di usia $\geq 45$ tahun meningkat 2,4 kali lebih besar pada perokok. ${ }^{4}$ Pembakaran rokok menghasilkan asap rokok yang tidak hanya berdampak bagi perokok aktif, namun juga untuk perokok pasif. Diketahui terdapat lebih dari 1,1 miliar perokok di seluruh dunia yang jumlahnya meningkat $2 \%$ setiap tahun dan sebanyak $40 \%$ anak-anak terpapar asap secondhand yang bertanggung jawab atas lebih dari 600.000 kematian per tahun. ${ }^{5,6}$ Berdasarkan data Riskesdas tahun 2013, prevalensi perokok pada penduduk Indonesia usia $>15$ tahun adalah $66 \%$ laki-laki dan $6,7 \%$ perempuan. Jumlah ini cenderung meningkat dari data Riskesdas tahun 2007. ${ }^{7}$ Selain itu, prevalensi perokok pasif di Indonesia diketahui jumlahnya lebih banyak dibandingkan dengan perokok aktif yang apabila dikategorikan berdasarkan tempat terpaparnya, yaitu 
sebesar $78,4 \%$ berada di dalam rumah dan $51,3 \%$ berada di kantor. ${ }^{8}$

Asap rokok merupakan sumber radikal bebas eksogenus yang diidentifikasi mengandung lebih dari 4000 bahan kimia diantaranya nikotin, ammonia, akrolein, fenol, asetaldehida, hidrokarbon aromatik polisiklik, polifenol, karbon monoksida, nitrogen oksida, hidrogen sianida, dan logam. ${ }^{9}$ Jumlah radikal bebas dalam setiap hembusan asap rokok dapat mencapai $10^{17}$ partikel radikal bebas yang dapat menjadi penyebab stress oksidatif, yaitu kondisi dimana beban oksidan yang berlebih pada tubuh sehingga menyebabkan terjadinya ketidakseimbangan antara produksi reative oxygen species (ROS) dan mekanisme pertahanan antioksidan pada tubuh. ${ }^{10,11,12}$ Stress oksidatif sering terkait dengan terjadinya kerusakan jaringan yang akan memicu terjadinya reaksi inflamasi. ${ }^{13}$ Inflamasi ini akan menimbulkan suatu reaksi respons inflamasi dalam tubuh terhadap organ yang meradang. Respon inflamasi mengakibatkan terjadinya leukositosis atau peningkatan jumlah leukosit untuk meningkatkan kekebalan tubuh dalam mempertahankan kondisi tubuh. ${ }^{14}$ Leukositosis dilihat sebagai penanda adanya inflamasi kronik, subklinis dan inflamasi tingkat rendah. ${ }^{15}$ Leukosit merupakan sel darah yang berperan dalam sistem pertahanan tubuh dari serangan zat asing dan sel-sel abnormal. ${ }^{16}$ Pengukuran kadar leukosit tergolong pengukuran yang murah, tersedia dan banyak digunakan, serta menggambarkan refleksi gelombang dan kekakuan arteri yang merupakan faktor penentu penting dari fungsi dan risiko kardiovaskular. ${ }^{17}$ Diketahui terdapat hubungan positif antara merokok dengan jumlah total leukosit pada perokok. $^{18}$ Seseorang yang mendapatkan paparan asap rokok dalam jangka waktu yang lama secara terus menerus memiliki jumlah leukosit 20-25\% lebih tinggi dibandingkan orang yang tidak merokok. ${ }^{18}$ Sebuah penelitian menyebutkan bahwa terdapat peningkatan total leukosit sebesar $87 \%$ pada tikus wistar yang diberi paparan asap rokok sebanyak 1 batang rokok selama 2 minggu. ${ }^{19}$ Akumulasi dan perekrutan leukosit yang terjadi secara terus-menerus berhubungan dengan proses pembentukkan plak. ${ }^{20}$ Plak ini rentan pecah, menyebabkan trombosis, infrak miokard atau stroke. ${ }^{20}$ Oleh karena itu, penurunan jumlah leukosit diharapkan dapat meminimalkan risiko tersebut. ${ }^{21}$

Penurunan jumlah leukosit dapat dipengaruhi oleh faktor asupan terutama yang mengandung antioksidan yaitu senyawa yang dapat menangkap atau meredam dampak negatif dari radikal bebas. ${ }^{22}$ Secara alami, tubuh telah memiliki antioksidan. Akan tetapi, apabila paparan radikal bebas terlalu banyak, antioksidan alami tersebut tidak mampu untuk mengatasinya. Dalam keadaan seperti ini maka tubuh memerlukan suplai antioksidan dari luar tubuh. Salah satunya adalah ubi jalar ungu. Ubi jalar dipilih karena toleransi dan adaptasinya yang baik terhadap kekeringan, tanah yang kurang subur, iklim, dan berbagai sistem pertanian di seluruh dunia. ${ }^{23}$ Selain dikenal sebagai bahan pangan dengan mutu kandungan gizi yang baik, ubi jalar juga merupakan pangan sumber karbohidrat yang memiliki indeks glikemik rendah sehingga aman bagi penderita diabetes mellitus. ${ }^{24,25}$ Ubi jalar juga memiliki potensi besar sebagai tanaman ketahanan pangan karena waktu tanamannya yang relatif singkat yaitu 3-4 bulan. ${ }^{26}$ Jenis ubi jalar sangat beragam, salah satunya adalah ubi jalar berdaging ungu. Warna ungu pada ubi jalar disebabkan oleh adanya pigmen ungu antosianin yang menyebar dari bagian kulit sampai daging ubinya. Antosianin pada ubi jalar memiliki kemampuan tinggi pada aktivitas antioksidan dan penangkapan radikal bebas. ${ }^{27}$ Kemampuan ini berperan dalam mencegah terjadinya penyakit degeneratif seperti aterosklerosis. ${ }^{28}$ Besar kecilnya konsentrasi antosianin menyebabkan beberapa jenis ubi jalar ungu mempunyai gradasi warna yang berbeda. $^{29}$ Ubi jalar ungu pekat mengandung antosianin sebesar $61,85 \mathrm{mg} / 100 \mathrm{~g}$ dan aktivitas antioksidan sebesar $59,25 \% .{ }^{30}$ Selain antosianin, kandungan antioksidan lain yang terdapat dalam ubi jalar ungu yaitu vitamin $C$ dan $\beta$-karoten. Menurut hasil penelitian Kemal dkk, ubi jalar ungu memiliki kandungan vitamin $\mathrm{C}$ dan $\beta$-karoten sebesar 0,0177 $\mathrm{mg}$ dan $0,1244 \mathrm{mg} / 100$ gram ubi. ${ }^{31}$ Sebuah penelitian menunjukkan bahwa potensi ubi jalar ungu sebagai antioksidan berpengaruh secara signifikan terhadap perubahan MDA dan SOD darah tikus diabetes mellitus yang diberikan ubi jalar ungu sebanyak 4 $\mathrm{ml} /$ hari selama 50 hari. $^{32}$ Penelitian lain yang dilakukan Jawi pada hewan coba yang dikondisikan hiperkolesterolemik menunjukkan bahwa pemberian $4 \mathrm{ml} /$ hari ubi jalar ungu mempunyai peran sebagai anti inflamasi yang secara signifikan menurunkan IL1 selama 60 hari. ${ }^{33}$ Penelitian mengenai pengaruh pemberian ubi jalar ungu terhadap kadar leukosit total tikus belum dilakukan. Sehingga hal ini menjadi latar belakang peneliti ingin mengetahui bagaimana pengaruh pemberian ubi jalar ungu (Ipomoea batatas L. Poir) terhadap kadar leukosit total tikus yang dipapar asap rokok.

\section{METODE}

Penelitian ini menggunakan desain post test only control group. Penelitian dilaksanakan pada bulan September sampai Oktober 2018. Pemeliharaan dan perlakuan pemaparan asap rokok dilakukan di Laboratorium Pusat Studi Pangan dan Gizi PAU Universitas Gadjah Mada Yogyakarta, sedangkan untuk pemeriksaan kadar leukosit total dilakukan di 
Rumah Sakit Hewan dr. Soeparwi Yogyakarta. Sampel tikus yang digunakan adalah tikus wistar jantan dengan kriteria inklusi berusia 12 minggu dengan berat berkisar antara 150-250 gram, tikus dalam kondisi sehat dan dapat menerima perlakuan sesuai prosedur penelitian. Kriteria eksklusinya adalah tikus mengalami penurunan berat badan $>10 \%$ dan mati saat penelitian berlangsung. Besar sampel ditentukan berdasarkan kriteria WHO dalam Research Guideline for Evaluating The Safety and Efficacy of Herbal Medicine, yaitu jumlah minimal 5 ekor tiap kelompok. Namun untuk mengantisipasi adanya tikus yang drop out dalam penelitian ini kami menambahkan 1 ekor tikus di setiap kelompok perlakuan sehingga total sampel yang digunakan menjadi 24 ekor.

Tikus diaklitimasi selama 7 hari di laboratorium dengan diberikan pakan dan minum secara ad libitum. Kemudian tikus wistar dibagi secara simple random sampling menjadi 4 kelompok yaitu kelompok $\mathrm{K}(-)$ yang mendapat pakan standar, kelompok $\mathrm{K}(+)$ yang diberi paparan asap rokok sebanyak 2 batang/hari, kelompok P1 yang diberi ubi jalar ungu sebanyak $8 \mathrm{~g} / 200 \mathrm{~g}$ berat badan tikus, dan kelompok P2 yang diberi paparan asap rokok sebanyak 2 batang/hari dan ubi jalar ungu $8 \mathrm{~g} / 200 \mathrm{~g}$ berat badan tikus. Tikus yang akan diberikan paparan asap rokok dimasukkan ke dalam smoking chamber. Pemaparan asap rokok dilakukan menggunakan smoking pump. Perlakuan dilakukan selama 30 hari. Lalu di hari ke 31 dilakukan pengukuran leukosit total setiap kelompoknya. Pengukuran kadar leukosit total dilakukan menggunakan metode Automatic Hematology Analyzer dengan alat hematology analyzer Mindray BC-2800 Vet.

Hasil pengukuran kadar leukosit total tiap kelompok selanjutnya diolah dan dilakukan analisis data. Uji normalitas data dilakukan menggunakan uji Saphiro-Wilk. Kemudian karena data berdistribusi normal, analisa data dilanjutkan dengan uji parametrik menggunakan One-way ANOVA. Batas nilai yang dianggap signifikan dalam penelitian ini adalah jika $\mathrm{p}<0,05$ dengan interval kepercayaan $95 \%$.

\section{HASIL}

\section{Rerata Berat Badan Tikus}

Berdasarkan tabel 1, diketahui terdapat peningkatan berat badan secara signifikan pada keempat kelompok perlakuan. Setelah dilakukan uji One-way ANOVA, terdapat perbedaan berat badan yang signifikan pada kelompok berat badan setelah perlakuan dan delta perubahan berat badan, sedangkan kelompok berat badan sebelum perlakuan tidak menunjukkan perbedaan yang signifikan. Perbedaan yang signifikan pada kelompok berat badan setelah perlakuan dan delta perubahan berat badan terdapat pada kelompok $\mathrm{K}(+)$.

Tabel 1. Rerata Perubahan Berat Badan Sebelum dan Sesudah Penelitian

\begin{tabular}{cccccc}
\hline Kelompok & $\begin{array}{c}\text { Sebelum } \\
\text { Rerata } \pm \text { SB }\end{array}$ & $\begin{array}{c}\text { Sesudah } \\
\text { Rerata } \pm \text { SB }\end{array}$ & $\boldsymbol{P}^{* *}$ & $\begin{array}{c}\Delta \text { Berat Badan } \\
\text { Rerata } \pm \text { SB }^{*}\end{array}$ & $\%$ \\
\hline $\mathrm{K}(-)$ & $169,0 \pm 17,63^{\mathrm{a}}$ & $222,6 \pm 17,72^{\mathrm{b}}$ & 0,000 & $53,6 \pm 1,34^{\mathrm{b}}$ & 32 \\
$\mathrm{~K}(+)$ & $174,2 \pm 10,89^{\mathrm{a}}$ & $199,2 \pm 11,75^{\mathrm{a}}$ & 0,000 & $25,0 \pm 2,44^{\mathrm{a}}$ & 14,3 \\
$\mathrm{P} 1$ & $175,0 \pm 13,96^{\mathrm{a}}$ & $225,8 \pm 13,33^{\mathrm{b}}$ & 0,000 & $50,8 \pm 1.92^{\mathrm{b}}$ & 29 \\
P2 & $187,8 \pm 11,18^{\mathrm{a}}$ & $240,8 \pm 9,03^{\mathrm{b}}$ & 0,000 & $53,0 \pm 3,39^{\mathrm{b}}$ & 28,2 \\
$P^{*}$ & 0,207 & 0,001 & & 0,000 & \\
\hline
\end{tabular}

Keterangan : K(-) : Kelompok tikus yang diberi pakan standar; $\mathrm{K}(+)$ : Kelompok tikus yang diberi paparan asap rokok 2 batang/hari; P1 : Kelompok tikus yang diberi ubi jalar ungu 8 g/200 g BB; P2 : Kelompok tikus yang diberi paparan asap rokok 2 batang/hari dan ubi jalar ungu $8 \mathrm{~g} / 200 \mathrm{~g} \mathrm{BB}$; * Uji One-way ANOVA; ** : Uji Paired T Test; ${ }^{\mathrm{a}, \mathrm{b}}$ : notasi yang berbeda pada kolom yang sama menunjukkan perbedaan yang signifikan ;

\section{Kadar Leukosit Total}

Berdasarkan tabel 2, diketahui bahwa hasil uji One-way ANOVA menunjukkan tidak terdapat perbedaan yang signifkan pada keempat kelompok perlakuan $(p>0.05)$. Rerata kadar leukosit paling tinggi terlihat pada kelompok $\mathrm{K}(+)$.

Tabel 2. Rerata Kadar Leukosit Total Post-Test

\begin{tabular}{ccccc}
\hline & Kelompok & $\mathbf{N}$ & Rerata \pm SB & $\boldsymbol{p}^{*}$ \\
\hline Leukosit & $\mathrm{K}(-)$ & 5 & $21.06 \pm 3.26^{\mathrm{a}}$ & \\
Total & $\mathrm{K}(+)$ & 5 & $23.56 \pm 3.10^{\mathrm{a}}$ & \\
$\left(\mathrm{ribu} / \mathrm{mm}^{3}\right)$ & $\mathrm{P} 1$ & 5 & $22.06 \pm 2.02^{\mathrm{a}}$ & 0.579 \\
& $\mathrm{P} 2$ & 5 & $21.36 \pm 3.52^{\mathrm{a}}$ & \\
\hline
\end{tabular}

Keterangan : $\mathrm{K}(-)$ : Kelompok tikus yang diberi pakan standar; $\mathrm{K}(+)$ : Kelompok tikus yang diberi paparan asap rokok 2 batang/hari; P1 : Kelompok tikus yang diberi ubi jalar ungu 8 g/200 g BB; P2 : Kelompok tikus yang diberi paparan asap rokok 2 batang/hari dan ubi jalar ungu 8

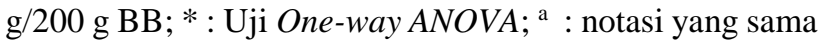
pada kelompok yang sama menunjukkan perbedaan yang tidak bermakna ;

\section{PEMBAHASAN}

Penelitian ini menggunakan desain post-test only control group dengan 4 kelompok perlakuan di dalamnya, yaitu kelompok $\mathrm{K}(-), \mathrm{K}(+), \mathrm{P} 1$ dan P2. Pemaparan asap rokok dan pemberian ubi jalar ungu 
dilakukan selama 30 hari. Perlakuan paparan asap rokok yang dilakukan menggunakan 2 batang rokok/hari dengan kandungan 2,4 mg nikotin dan 38 $\mathrm{mg}$ tar selama \pm 30 menit bertujuan untuk menimbulkan respon inflamasi yang dilihat melalui kadar leukosit total. Kadar kandungan ini jumlahnya melebihi dari batas ketentuan nikotin dan tar yang diperbolehkan. Dalam Pasal 4 Peraturan Pemerintah Nomor 81 Tahun 1999 menetapkan bahwa batas kadar maksimum kandungan nikotin dan tar pada setiap batang rokok yang beredar di wilyah Indonesia tidak boleh melebihi kadar kandungan nikotin 1,5 mg dan kadar kandungan tar 20 mg. ${ }^{34}$

Paparan asap rokok dapat meningkatkan kadar leukosit total disebabkan adanya inflamasi dari zat dalam asap rokok. Asap rokok merupakan salah satu jenis radikal bebas eksogenus yang mengandung lebih dari 4.000 komponen bahan kimia toksik dan karsinogenik, seperti nikotin, nitrogen oksida, karbon monoksida, hidrogen sianida dan radikal bebas lainnya. ${ }^{35}$ Setiap hembusan asap rokok dapat mengandung $10^{17}$ radikal bebas. ${ }^{10}$ Paparan asap rokok dapat menyebabkan tubuh mengalami keadaan stress oksidatif dan kenaikan leukosit total sebagai tanda adanya inflamasi. Berdasarkan hasil penelitian ini, kelompok tikus yang diberi paparan asap rokok saja menunjukkan nilai kadar leukosit paling tinggi diantara kelompok perlakuan lainnya dengan rerata $23,56 \times 10^{3} / \mathrm{mm}^{3}$. Kenaikan leukosit total menjadi respon alamiah tubuh karena masuknya zat asing. Nikotin dalam asap rokok dapat menyebabkan leukositosis dengan bersirkulasinya katekolamin karena kenaikan hormon seperti epinephrine dan kortisol yang pada akhirnya akan meningkatkan jumlah leukosit total. ${ }^{36,37}$ Selain itu, radikal bebas dari asap rokok yang masuk ke dalam tubuh akan mengaktivasi sinyal kaskade intraseluler pada sel epitel yang memicu aktivasi mediator inflamasi seperti protein fase akut dan sitokin pro inflamasi [seperti IL-8 dan tumor necrosis factor-alpha $(\mathrm{TNF} \alpha)$ ]. Sekresi mediator inflamasi menyebabkan pembentukan sel imun dan inflamasi sehingga terjadi respon inflamasi berupa pelepasan leukosit ke sirkulasi. ${ }^{38,39,40,41}$

Leukositosis pada perokok mencerminkan adanya respon peradangan tingkat rendah dan merupakan faktor risiko dari terjadinya penyakit jantung koroner, sedangkan penurunan jumlah leukosit mencerminkan perbaikan peradangan sistemik dan peradangan endotel vaskular. ${ }^{42,43}$ Penurunan jumlah leukosit dapat dipengaruhi oleh faktor asupan terutama yang mengandung antioksidan. Hal ini didukung oleh penelitian sebelumnya yang menyebutkan bahwa pemberian jus tomat sebagai salah satu bahan makanan yang mengandung antioksidan selama 1 bulan pada kelompok tikus yang diberi paparan asap rokok dapat memberikan nilai kadar leukosit total yang lebih rendah dibandingkan kelompok yang tidak diberi jus tomat. ${ }^{19}$

Ubi jalar ungu yang digunakan dalam penelitian ini mengandung antioksidan yang dapat menangkap radikal bebas dari asap rokok. Warna ungu pada ubi jalar ungu disebabkan oleh adanya antosianin yang memiliki kemampuan tinggi pada aktivitas antioksidan dan penangkapan radikal bebas. ${ }^{27}$ Antosianin tidak hanya memiliki fungsi sebagai antioksidan, tetapi juga sebagai anti inflamasi. Peranan anti inflamasi dari antosianin yaitu dengan memblokir dua jalur perisnyalan utama seperti NF-kB dan mitogen-activated protein kinase (MAPKs) yang memiliki peran utama dalam produksi berbagai mediator pro inflamasi. ${ }^{44}$ Penelitian yang dilakukan pada subjek dewasa sehat menunjukkan bahwa pemberian suplementasi antosianin menghambat aktivasi NF-kB pada monosit dengan menurunkan plasma konsentrasi dari kemokin pro inflamasi, sitokin, dan mediator respon inflamasi. ${ }^{45}$ Mekanisme yang mungkin terlibat disini adalah antosianin, produk hasil pemecahannya, atau metabolitnya menekan stress oksidatif dengan mengikat ROS secara langsung sehingga respon inflamasi dapat diredam. ${ }^{45}$ Antosianin berperan sebagai antioksidan melalui kemampuannya yang secara langsung dapat mengganggu reaksi berantai radikal bebas dengan mendonorkan atom hidrogen ke radikal peroksil membentuk radikal yang tidak aktif. $^{46,47}$ Selain antosianin, ubi jalar ungu juga mengandung vitamin $C$ dan $\beta$-karoten yang termasuk dalam antioksidan non enzimatik. Paparan asap rokok diketahui menurunkan kadar vitamin $\mathrm{C}$ dan $\beta$-karoten pada hewan coba. ${ }^{48}$ Vitamin $\mathrm{C}$ efektif dalam mengikat anion radikal superoksida, hidrogen peroksida, radikal hidroksil, oksigen singlet dan oksigen nitrogen reaktif, sedangkan $\beta$-karoten berperan sebagai antioksidan dengan menonaktifkan radikal bebas dan singlet oksigen melalui proses yang disebut sebagai peredam. ${ }^{49,50}$ Sebuah penelitian menunjukkan bahwa potensi ubi jalar sebagai antioksidan berpengaruh secara signifikan terhadap perubahan MDA dan SOD darah tikus DM yang diberikan ubi jalar ungu sebesar $4 \mathrm{ml} / \mathrm{hari}$ selama 50 hari. ${ }^{32}$ Pada penelitian lain, pemberian $4 \mathrm{ml} /$ hari ubi jalar ungu selama 60 hari terlihat memberikan efek anti inflamasi yang ditunjukkan dengan adanya penurunan kadar IL-1 secara signifikan pada tikus hiperkolesterolemik. ${ }^{33}$ Pada penelitian ini, pemberian ubi jalar ungu pada kelompok tikus yang diberikan paparan asap rokok menunjukkan kadar leukosit total yang hampir mendekati kadar leukosit total pada kelompok K(-). 
Namun berdasarkan hasil analisis uji Oneway ANOVA didapatkan nilai signifikansi sebesar 0,579 yang berarti tidak terdapat perbedaan kadar leukosit total yang bermakna pada keempat kelompok perlakuan. Hal ini tidak sejalan dengan penelitian sebelumnya yang menunjukkan bahwa pemaparan 2 batang rokok/hari dengan kandungan nikotin dan tar yang sama dalam satu batang rokoknya pada kelompok kontrol secara signifikan memberikan hasil kadar leukosit total yang berbeda diantara kelompok perlakuan. $^{51}$ Subjek dikatakan mengalami leukositosis ketika kadar leukosit dalam tubuhnya meningkat $35 \%$ dari nilai normal. ${ }^{52}$ Jika nilai leukosit total pada penelitian ini dibandingkan dengan nilai normal leukosit total pada tikus wistar yaitu 5-8,96 x $10^{3} / \mathrm{mm}^{3}$ dapat dikatakan pada akhir penelitian semua kelompok tikus mengalami leukositosis. ${ }^{52}$

Berdasarkan data berat badan pada tabel 1 , terlihat bahwa terjadi peningkatan berat badan pada semua kelompok perlakuan selama penelitian berlangsung. Pada kelompok K(-), P1 dan P2 terjadi peningkatan berat badan sebesar $>20 \%$ dari berat badan awal, sedangkan pada kelompok $\mathrm{K}(+)$ tikus mengalami peningkatan berat badan yang lebih rendah yaitu sebesar 14\%. Menurut Yuniarto, tikus yang mengalami pertambahan berat badan sebesar $20 \%$ dari berat badan awal dapat dikatakan tikus mengalami obesitas. ${ }^{53}$ Obesitas merupakan keadaan dimana terjadi ketidaknormalan atau kelebihan akumulasi lemak dalam tubuh yang disimpan dalam jaringan adiposa. ${ }^{54}$ Jaringan adiposa merupakan suatu model terintegrasi antara sistem endokrin dan signaling dalam regulasi metabolisme energi. ${ }^{55}$ Jaringan adiposa tersusun atas kumpulan sel-sel adiposit yang tidak hanya berfungsi sebagai penyimpanan lemak, tetapi juga berfungsi sebagai pengatur keseimbangan energi dan homeostasis tubuh. ${ }^{56}$

Pada subjek yang mengalami obesitas, adanya keadaan inflamasi kronik tingkat rendah disebabkan oleh peningkatan produksi dan sekresi sitokin pro inflamasi seperti TNF- $\alpha$ dan IL-6 serta adipokin dari jaringan adiposa dan leukosit. $54,57,58$ Berdasarkan hasil sebuah penelitian diketahui bahwa terdapat hubungan antara obesitas dengan leukositosis. $^{58}$ Penelitian tersebut sesuai dengan penelitian yang dilakukan oleh Shabbir, dkk bahwa terdapat peningkatan leukosit yang signifikan pada tikus obes karena pemberian diet tinggi lemak. ${ }^{59}$ Meningkatnya produksi dan sekresi sitokin dari jaringan adiposa menyebabkan peningkatan produksi dan aktivasi leukosit. ${ }^{60,61}$

Lebih lanjut lagi diketahui peningkatan jumlah leukosit pada keadaan obesitas mungkin di mediasi oleh peningkatan kadar leptin yang disekresikan oleh jaringan adiposa. $^{62}$ Leptin mempunyai hubungan positif dengan persen lemak tubuh. ${ }^{63}$ Kadar leptin dalam sirkulasi meningkat pada keadaan obesitas. ${ }^{64}$ Inflamasi pada obesitas terjadi karena leptin mengaktifkan faktor transkripsi Nuclear Factor kappa Beta (NF-kB). NF-kB yang teraktivasi akan menginduksi transkripsi gen inflamasi diantaranya sitokin pro inflamasi TNF- $\alpha$ dan beberapa molekul adesi seperti ICAM-1 maupun VCAM. ${ }^{65,66}$ Leukosit kemudian akan teraktivasi oleh sekresi dari sitokin ini. Selain itu, leptin juga diketahui mempunyai peran dalam lymphopoiesis dan myelopoiesis. ${ }^{67}$ Berdasarkan pemaparan ini dapat disimpulkan bahwa hasil penelitian yang menunjukkan tidak adanya perbedaan yang signifikan disebabkan tikus pada kelompok $\mathrm{K}(-), \mathrm{P} 1$ dan P2 berada dalam keadaan leukositosis karena tikus mengalami obesitas, sedangkan pada kelompok $\mathrm{K}(+)$ peningkatan kadar leukosit disebabkan karena paparan asap rokok.

\section{KETERBATASAN PENELITIAN}

Tidak dilakukannya pengukuran terhadap panjang nasoanal tikus yang dapat digunakan untuk menentukan besar Indeks Obesitas Lee. Parameter Indeks Obesitas Lee dapat digunakan untuk menentukan apakah hewan coba termasuk ke dalam kategori obesitas atau tidak.

\section{KESIMPULAN}

Berdasarkan hasil penelitian yang dilakukan selama 30 hari dapat disimpulkan bahwa pemberian ubi jalar ungu menunjukkan tidak adanya perbedaan yang bermakna terhadap kadar leukosit total tikus.

\section{SARAN}

Penelitian selanjutnya diharapkan peneliti memastikan tikus dalam kondisi sehat sebelum memulai perlakuan dan dapat dilakukan pengukuran panjang nasoanal dari hewan coba yang digunakan.

\section{DAFTAR PUSTAKA}

1. Abikoye GE, Kashimawo AJ, Eze CU. Tobacco Smoking and Awareness of Smoking-cessation Products in a University Community. J Public Heal Epidemiol. 2013;5(8):351-6.

2. Chapple ILC, Matthews JB. The Role of Reactive Oxygen and Antioxidant Species in Periodontal Tissue Destruction. Periodontol 2000. 2007;43:160-232.

3. Vardavas CI, Anagnostopoulos N, Kougias M, Evangelopoulou V, Connolly GN, Behrakis PK. Short-term Pulmonary Effects of Using an Electronic Cigarette. Chest. 2012;141(6):14006.

4. Supriyono M. Faktor-faktor Risiko yang Berpengaruh terhadap Kejadian Penyakit 
Jantung Koroner pada Kelompok usia $\leq 45$ Tahun (Studi Kasus di RSUP Dr. Karyadi dan RS Telogorejo Semarang) [Tesis]. Universitas Diponegoro; 2008.

5. World Health Organization. WHO Report on the Global Tobacco Epidemic. Geneva, Swizerland; 2008.

6. World Health Organization. Global Health Observatory (GHO) data : Second-hand smoke. Geneva, Swizerland; 2016.

7. Kementrian Kesehatan RI. INFODATIN Perilaku Merokok Masyarakat Indonesia berdasarkan Risekesdas 2007 dan 2013. Jakarta: Kementerian Kesehatan RI; 2015.

8. Balitbangkes R. Global Adult Tobacco Survey: Indonesia report 2011. Indonesia; 2012.

9. Kamceva G, Arsova-Sarafinovska Z, Ruskovska T, Zdravkovska M, Kamceva-Panova L, Stikova E. Cigarette Smoking and Oxidative Stress in Patients with Coronary Artery Disease. J Med Sci. 2016;4(4):636-40.

10. Bajic V, Bajic B, Ć ZM, Ć SR, Nikolau A. Oxidative Stress is Reduced in Wistar Rats Exposed to Smoke from Tobacco and Treated with Spesific Broad-band Pulse Electromagnetic Fields. ArchBiolSciBelgrade. 2009;61(3):35366.

11. Kirkham P, Rahman I. Oxidative stress in asthma and COPD: Antioxidants as a therapeutic strategy. Pharmacol dan Ther. 2006;111:476-94.

12. Makker K, Agarwal A, Sharma RK. Oxidative Stress and Male Infertility. Indian J Med Res. 2009;129(4):357-67.

13. Kumar V, Abbas AK, Aster JC, Robbins SL. Robbins Basic Pathology. Philadelphia: Elsevier Saunders; 2005.

14. Dorland WAN. Kamus Kedokteran Dorland Terjemahan. Jakarta: EGC; 2002.

15. Bonaterra, G A, Zügel S, Kinscherf R. Novel Systemic Cardiovascular Disease Biomarkers. Curr Mol Med. 2010;10:180-205.

16. Guyton AC, Hall J. Buku Ajar Fisiologi Kedokteran 12th Edition. Jakarta: EGC Kedokteran.; 2014.

17. Vlachopoulos C, Konstantinos A, Pietri P, Ioakeimidis N, Stefanadis C. White Blood Cell Count is a Marker of Wave Reflections and Arterial Stiffness in Healthy Individuals. Atherosclerosis. 2006;187:218-9.

18. Haider MJ, Rauf A. Smoking habits and their association with total leukocytes count among healthy men in Karachi, Pakistan. World Appl Sci J. 2010;11(6):669-73.

19. Suryani AI, Johan A. Efek Jus Tomat terhadap Jumlah Total Leukosit dan Neutrofil Tikus
Wistar yang Leukositosis Setelah Diberi Paparan Asap Rokok. J Kedokt Diponegoro. 2011;1(1):1-11.

20. Woollard KJ, Geissmann F. Monocytes in Atherosclerosis: Subsets and Functions. Nat Rev Cardiol. 2010;7(2):77-86.

21. Coller BS. Leukocytosis and Ischemic Vascular Disease Morbidity and Mortality: Is It Time to Intervene? Arterioscler Thromb Vasc Biol. 2005;25(4):658-70.

22. Sayuti K, Yenrina R. Pengertian Antioksidan dan Manfaatnya. In: Antioksidan, Alami dan Sintetik. Padang: Andalas University Press; 2015. p. 7.

23. Ji H, Zhang H, Li H, Li Y. Analysis on the Nutrition Composition and Antioxidant Activity of Different Types of Sweet Potato Cultivars. Food Nutr Sci. 2015;6:161-7.

24. Jusuf M, Rahayuningsih SA, Ginting E. Ubi Jalar Ungu. War Penelit dan Pengemb Pertan. 2008;30(4):13-4.

25. UPT Balai Pengembangan Proses dan Teknologi Kimia. Laporan Akuntabilitas Kinerja Instansi Pemerintah Tahun 2011 (LAKIP) UPT BPPTK LIPI. Yogyakarta: Lembaga Ilmu Pengetahuan Indonesia UPT Balai Pengembangan Proses dan Teknologi Kimia; 2011.

26. L Adepoju A, A Adejumo B. Some Proximate Properties of Sweet Potato (Ipomoea Batatas L) As Influenced by Cooking Methods. Int J Sci Technol Res. 4AD;3(146-148).

27. Oki T, Masuda M, Furuta S, Nishiba Y, Terahara N, Suda I. Involvement of Anthocyanins and Other Phenolic Compounds in RadicalScavenging Activity of Purple-Fleshed Sweet Potato Cultivars. J Food Sci. 2002;67(5):17526.

28. Miyazaki K, Makino K, Iwadate E, Deguchi Y, Ishikawa F. Anthocyanins from Purple Sweet Potato Ipomoea batatas Cultivar Ayamurasaki Suppress the Development of Atherosclerotic Lesions and Both Enhancements of Oxidative Stress and Soluble Vascular Cell Adhesion Molecule-1 in Apolipoprotein E-Deficient Mice. J Agric Food Chem. 2008;56(23):11485-92.

29. Yang J, Gadi RL. Effect of Steaming and Dehydration on Anthocyanins, Antioxidant Activity, Total Phenols and Color Characteristics of Purple Fleshed Sweet Potatoes (Ipomoea batatas). Am J Food Technol. 2008;3(4):224-34.

30. Husna N El, Novita M, Rohaya S. Kandungan Antosianin dan Aktivitas Antioksidan Ubi Jalar Ungu Segar dan Produk Olahannya. AGRITECH. 2013;33(3):296-302.

31. Kemal NN, Karim A, Asmawati, Seniwati. 
Analisis Kandungan $\beta$-Karoten dan Vitamin C dari Berbagai Varietas Ubi Jalar (Ipomoea batatas). Indones Chem Acta. :1-8.

32. Jawi IM, Sumardika IW, Linawati NM. Pencegahan Gangguan Fungsi Ginjal Karena Stress Oksidatif pada Tikus Diabetes dengan Ubi Jalar Ungu. J Veteriner. 2014;15(2):274-80.

33. Jawi IM, Indrayani AW, Sutirta-Yasa IWP. Aqueous Extract of Balinese Purple Sweet Potato (Ipomoea batatas L.) Prevents Oxidative Stress and Decreases Blood Interleukin-1 in Hypercholesterolemic Rabbits. Bali Med J (Bali Med J). 2015;4(1):37-40.

34. Kementrian Perdagangan Republik Indonesia. Peraturan Pemerintah Republik Indonesia Nomor 81 Tahun 1999 tentang Pengamanan Rokok Bagi Kesehatan [Internet]. Jakarta; 1999. Available

from: http://www.kemendag.go.id/files/regulasi/1999/ 10/Pp81-99.PDF

35. Ahmed OA. Effects of Smoking Cigarette on White Blood Cell and Platelet Parameter on a Sample of Normal Subject in Rania City. Imp J Interdiscip Res. 2016;2(6):887-92.

36. Kapoor D, Jones TH. Smoking and Hormones in Health and Endocrine Disorders. Eur J Endocrinol. 2005;151:491-9.

37. Deutsch, Varlerner-Geva L, Reches A, Boyko V, Limor R, Grisaru D. Sustained Leukocyte Count during Rising Cortisol Level. Acta Haematol. 2007;118:73-6.

38. Chung KF. Inflammatory Mediators in Chronic Obstructive Pulmonary Disease. Curr Drug Targets-Inflammation Allergy. 2005;4(6):61925.

39. Churg A, Dai J, Tai H, Xie C, Wright JL. Tumor Necrosis Factor- $\alpha$ Is Central to Acute Cigarette Smoke-induced Inflammation and Connective Tissue Breakdown. Am J Respir Crit Care Med. 2002;166(849-854).

40. Lee J, Taneja V, Vassallo R. Cigarette Smoking and Inflammation: Celllular and Molecular Mechanisms. J Dent Res. 2012;90(2):142-9.

41. Eeden SF Van, Yeung A, Quinlam K, Hogg JC. Systemic Response to Ambient Particulate Matter Relevance to Chronic Obstructive Pulmonary Disease. Proc Am Thorac Soc. 2005;2:61-7.

42. Lee YJ, Lee JW, Kim JK, Lee JH, Kim JH, Kwon KY, et al. Elevated White Blood Cell Count is Associated with Arterial Stiffness. Nutr Metab Cardiovasc Dis. 2009;19:3-7.

43. Higuchi T, Omata F, Tsuchihashi K, Higashioka $\mathrm{K}$, Koyamada R, Okada S. Current cigarette smoking is a reversible cause of elevated white blood cell count: Cross-sectional and longitudinal studies. Prev Med Reports. 2016;4:417-22.

44. Arulselvan P, Fard MT, Tan WS, Gothai S, Fakurazi S, Norhaizan ME, et al. Role of Antioxidants and Natural Products in Inflammation. Oxid Med Cell Longev. 2016;115.

45. Karlsen A, Retterstol L, Laake P, Paur I, Kjolsrud-Bohn S, Sandvik L, et al. Anthocyanins Inhibit Nuclear Factor-kB Activation in Monocytes and Reduce Plasma Concentrations of Pro-Inflammatory Mediators in Healthy Adults. J Nutr. 2007;137:1951-4.

46. Reis JF, Monteiro VVS, Gomes R de S, Carmo MM do, Costa GV da, Ribera PC, et al. Action Mechanism and Cardiovascular Effect of Anthocyanins : a Systematic Review of Animal and Human Studies. J Transl Med. 2016;14(315):1-16.

47. Prochazkova D, Bousova I, Wilhelmova N. Antioxidant and Prooxidant Properties of Flavonoids. Fitoterapia. 2011;82:513-23.

48. Ozkol H, Tuluce Y, Koyuncu I. Subacute Effect of Cigarette Smoke Exposure in Rats : Protection by Pot Marigold (Calendula officinalis L.) Extract. Toxicol Ind Health. 2012;28(1):3-9.

49. Carocho M, Ferreira ICFR. A Review on Antioxidants, Prooxidants and Related Controversy: Natural and Synthetic Compounds, Screening and Analysis Methodologies and Future Perspectives. Food Chem Toxicol. 2013;51:15-25.

50. Tahira R, Rehman A, Nagra S. Comparison of Serum $\beta$-carotene and Retinol in Smokers and Non-smokers. Int J Agri Biol. 2003;5(4):452-4.

51. Permatasari DN, Probosari E. Pengaruh Pemberian Sari Batang Nanas (Ananas comosus) terhadap Total Leukosit Tikus Wsitar yang diberi Paparan Asap Rokok. J Nutr Coll. 2015;4(2).

52. Mitruka BM, Rawnsley HM. Clinical Biochemical and Hematological Reference Values in Normal Experimental Animals and Normal Humans. New York: Masson Pub. USA; 1981.

53. Yuniarto A, Kurnia I, Ramadhan M. Antiobesity Effect of Ethanolic Extract of Jasmine Flowers (Jasminumsambac(1)Ait) in High-fat Diet-induced Mice: Potent Inhibitor of Pancreatic Lipase Enzyme. IJAPBC. 2015;4(1):18-22.

54. Nelms M, Sucher K, Lacey K, Roth S. Nutrition Therapy \& Pathopysiology. 2nd Edition. Wadsworth: Yolanda Cossio; 2010. 325 p.

55. Flier JS, Maratos-Flier E. Biology of Obesity. In: Jameson JL, editor. Harrison's Endocrinology. 
2nd Editio. USA: McGraw-Hill Professional; 2010. p. 242.

56. Bernlohr DA, Jenkins AE, Bennaars AA. Adipose Tissue and Lipid Metabolism. In: Vance JE, Vance D, editors. Biochemistry of Lipids, Lipoproteins and Membrans. 4th Editio. USA: Elsevier Science; 2002. p. 263-89.

57. Lago F, Dieguez C, Gomez-Reino J, Gualillo O. The Emerging Role of Adipokines as Mediators of Inflammation and Immune Responses. Cytokine Growth Factor Rev. 2007;18:313-25.

58. Sait Sait S, M Alqassas, S Othman, SB Shihon, L Alqalayta, S Alqusair, et al. Obesity Correlates with Neutrophilia. Hematol Transfus Int J. 2016;3(2):159-62.

59. Shabbir F, Hussain MM, Rajput TA. Obesity; Effect of High Fat Diet Followed by Atorvastatin Administration On Serum Interleukin-6, White Blood Cell and Platelet Count in Male and Female Sprague Dawley Rats. Prof Med J. 2015;22(6):683-9.

60. Mahmoud AM. Hematological Alterations in Diabetic Rats Role of Adipocytokines and Effect of Citrus Flavonoids. EXCLI J. 13AD;12:64757.

61. Farhangi MA, Keshavarz SA, Eshraghian M, Ostadrahimi A, Saboor-Yaraghi AA. White Blood Cell Count in Women: Relation to Inflammatory Biomarkers, Haematological Profiels, Visceral Adiposity, and Other
Cardiovascular Risk Factors. J Heal Popul Nutr. 2013;31(1):58-64.

62. Mabuchi T, Yatsuya H, Tamakoshi K, Otsuka R, Nagasawa $\mathrm{N}$, Zhang $\mathrm{H}$, et al. Association Between Serum Leptin Concentration and White Blood Cell Count in Middle-aged Japanese Men and Women. Diabetes Metab Res Rev. 2005;21:441-7.

63. Bell LN, Considine R V. Leptin and Obesity. In: Castracane VD, Henson MC, editors. Leptin. Switzerland: Springer Science; 2006. p. 33-51.

64. Trottier MD, Naaz A, Li Y, Fraker PJ. Enhancement of Hematopoiesis and Lymphopoiesis in Diet-induced Obese Mice. Proc Natl Acad Sci. 2012;109(20):7622-9.

65. Fatmawati H, Satuman, SW E, Rudijanto A, Indra MR. Pengaruh Likopen terhadap Penurunan Aktivitas Nuclear Factor kappa Beta (NF-kB) dan Ekspresi Intracelular Cell Adhesion Molecule-1 (ICAM-1) pada Kultur HUVECs yang Dipapar Leptin. J Ilmu Dasar. 2010;11(2):143-50.

66. Liu T, Zhang L, Joo D, Sun S-C. NF-kB Signaling in Inflammation. Signal Transduct Target Ther. 2017;2:1-9.

67. Claycombe K, King LE, Fraker PJ. A Role for Leptin in Sustaining Lymphopoiesis and Myelopoiesis. Proc Natl Acad Sci. 2008;105(6):2017-21. 